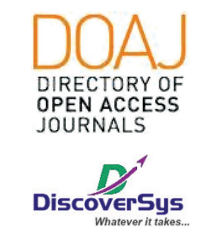

Published by DiscoverSys

\section{Association between parents' body height with stunting in children ages 1-5 years old in Nagi Primary Health Care Working Area Larantuka City, East Flores, Indonesia}

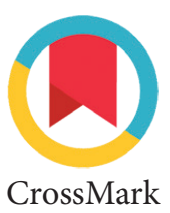

CrossMark

\author{
Wega Upendra Sindhughosa, ${ }^{*}$ I Made Arimbawa
}

\section{ABSTRACT}

Background: Parents' body height is one factor associated with stunting incidence in the child. In under-five years old children, the body height is influenced by genetic factors and the environment during development periods. Short mothers are one of the factor that related to the incidence of stunting. This study aims to determine the associations of parents' body height with stunting in children age 1-5 years old in Nagi Primary Health Care working area, Larantuka City. Methods: A cross-sectional study was conducted among 123 children age 1-5 years old who met the inclusion criteria were included in this study at Nagi Primary Health Care, Larantuka City. Data was taken from primary data and questionnaire distributed that consist of 3 main parts contains research sample characteristics, father's body height, and mother's body height. Chi-square is used to analyze the relationship between the father's body height and mother's body height with stunting. All of the data were analyzed using SPSS version 17 for Windows.

Results: Most of the respondents were female (53.7\%), followed by having a normal body height (67.5\%), normal body weight (97.6\%), $>155 \mathrm{~cm}$ of mother's body height (65.0\%), and $>165 \mathrm{~cm}$ of father's body height (62.6\%). In bivariate analysis, there is no relationship between father's body height with stunting ( $p>0.01$ ), but statistically significant between mother's body height with stunting $(p<0.01)$. In addition, a moderate positive correlation was found between Mid-Parental Height (MPH) with the children body weight $(r=0.41$; $\mathrm{p}=0.01$ ).

Conclusion: Mother's body height had a significant association with stunting incidence. In addition, the MPH also had a moderate positive correlation to the children body height.
Department of Pediatrics, Faculty of Medicine, Universitas Udayana, Sanglah General Hospital, Bali, Indonesia

*Correspondence to:

Wega Upendra Sindhughosa; Department of Pediatrics, Faculty of Medicine, Universitas Udayana, Sanglah General Hospital, Bali, Indonesia;

wegaupendra@gmail.com

Received: 2019-07-15

Accepted: 2020-03-24

Published: 2020-04-01
Keywords: body height, stunting, children, primary health care

Cite This Article: Sindhughosa, W.U., Arimbawa, I.M. 2020. Association between parents'body height with stunting in children ages 1-5 years old in Nagi Primary Health Care Working Area Larantuka City, East Flores, Indonesia. Intisari Sains Medis 11(1): 315-319. D0I: 10.15562/ism.v11i1.567

\section{INTRODUCTION}

The level of success of a nation's development is determined by the availability of quality human resources (HR) who have good physical health, strong mentality, and intelligence. ${ }^{1}$ Empirical evidence that this is primarily determined by good nutritional status, and proper nutritional status is determined by the amount of food consumed. ${ }^{1}$

Stunting is a linear growth disorder caused by malnutrition of chronic nutrient intake and/or chronic and recurrent infectious diseases as indicated by z-scores of body height according to age (H/A) less than -2 standard deviation (SD) based on World Health Organization standards. ${ }^{2}$ Some studies showed that children who experience stunting have a risk of death four times higher than children who do not have stunting as well as experience a decrease in IQ at least 11 points. ${ }^{2}$ When stunting children become adults, they will have $22 \%$ lower income and contributes to a decline per capita income of $16 \%$ in a country.

According to Milman et al., stunting conditions in children under-five years old can cause impairment in the development of cognitive and psychomotor function as well as decreased productivity when adults. ${ }^{3}$ Kusharisupeni in 2002 also stated that several factors thought to be related to stunting incidents in infants include birth weight, history of infectious toddlers, history of diseases during pregnancy, parental height, and socio-economic factors. ${ }^{4}$ Parent's body height is related to the child's physical growth. Short mothers are one of the factors associated with the incidence of stunting. ${ }^{4}$ In infants, height is influenced by genetic and environmental factors during the period of growth. Failure of linear growth is mostly caused due to the intrauterine period and the first few years of life are caused by inadequate intake and frequent infections. ${ }^{5}$

Based on data from the 2010 Basic Health Research (Riset Kesehatan Dasar/ Riskesdas), the prevalence of children under five years old with stunting in Indonesia reached $35.6 \%$, with the highest number occurring among children aged 24-36 months, $41.4 \%{ }^{6}$ The stunting prevalence 
rate is higher than the prevalence of moderately malnourished and severely malnourished $17.9 \%$, children under-five years old are very thin and thin count $13.3 \%$, and children under five years old are obese count 14\%. Data from the 2013 Basic Health Research also showed the prevalence of stunting in children under five years old increased to $37.2 \%$. The prevalence of moderately and severely malnourished even increased to $19.5 \% .^{7}$ But the prevalence of very thin and thin under-five years old children has decreased to $12.1 \%$. In comparison, the prevalence of obese under-five years old children has reduced to $11.9 \%$.

Based on the results of Nutrition Status Monitoring in 2017, East Nusa Tenggara (ENT) is the province with the highest number of moderately and severely malnourished under-five years old children in Indonesia (22.6\%) based on weight index per age, then 2018 in ENT has a high percentage of stunting, $42.6 \% .^{7}$ Therefore the authors are interested in examining more deeply the associations between parents' body height and the incidence of stunting in children ages 1-5 years in the working area of Nagi Primary Health Center, Larantuka City, East Flores. This research hopefully, can be the basis for planning health promotion and education related to diet recommendations and knowing the risk factors for stunting in Larantuka City, East Flores Regency.

\section{METHODS}

\section{Research Samples}

This study was conducted using a cross-sectional research method where data was taken at a particular time without any follow-up of the data. Data came from primary data where the authors distributed questionnaires consisting of 3 main parts which included the characteristics of sample study, father's body height, and mother's body height. Samples were taken from children aged 1 to 5 years old in the work area of Nagi Primary Health Center, Larantuka City in the period of August to September 2018. To be a sample of this study, parents/guardians must sign a letter of consent to be the subject of research. Respondents who were unable to provide information entirely or unwilling to give information were excluded from this study.

\section{Research Variables}

The main variables examined in this study were age, gender, father's body height, mother's body height, child's weight, child's body height, and calculation of MPH (mid parental height). Stunting children are defined as children who have a $\mathrm{Z}$ score less than -2SD on a WHO curve based on body height and age. MPH (mid parental height) is a calculation that can be used to estimate a child's body height as an adult based on parent's body height and gender.

\section{Statistical Analysis}

Independent variable that examined in this study was the body height of parents with the dependent variable was stunting. Data is processed in the form of categorical data and displayed in the form of a $2 \times 2$ table. The statistical analysis used is Chi-square. Then, a categorical Chi-square comparative analysis was also conducted with the independent variable of parent's body height and the dependent variable was stunting. All of the data were analyzed using SPSS version 17 for Windows.

\section{RESULTS}

There are more female respondents compared to male, with a percentage of $53.7 \%$ (Table 1). The age of the samples was in the range of 12 months to 60 months, with an average age of $28.9 \pm 12.5$ months. As many as $53.7 \%$ of children are female, and $46.3 \%$ are male. Children's body height ranges from $68 \mathrm{~cm}$ to $109 \mathrm{~cm}$, with an average of $85.4 \pm 9.8 \mathrm{~cm}$ while their body weight ranges from $6.5 \mathrm{~kg}$ to $16.1 \mathrm{~kg}$, with an average of $10.9 \pm 2.1 \mathrm{~kg}$ (Table 1). After grouping them, it was found that $32.5 \%$ of children are stunting. The average of father's body height is $161 \pm 9.5 \mathrm{~cm}$ with minimum and maximum body height respectively $143 \mathrm{~cm}$ and $186 \mathrm{~cm}$ while the mean body height of the mother is $156 \pm 6.9 \mathrm{~cm}$ with a minimum height of $140 \mathrm{~cm}$ and a maximum of $178 \mathrm{~cm}$. In this study also measured Mid- Parental Height (MPH) with an average of $158 \pm 9.8 \mathrm{~cm}$ with the lowest and highest $\mathrm{MPH}$, respectively $141 \mathrm{~cm}$ and $184 \mathrm{~cm}$ (Table 1).

In this study, it was found that all stunting respondents, $28.3 \%$ of respondents had father's body height less than $165 \mathrm{~cm}$. The analysis was not statistically significant with a value of $\mathrm{p}=0.43$ with confidence interval 0.46-1.39 (Table 2). Also, it was found that all stunting respondents, which is $51.2 \%$ of respondents, had a mother's body height less than $155 \mathrm{~cm}$. The analysis was found statistically significant with a value of $\mathrm{p}<0.01$ and a confidence interval of 1.37-3.75 (Table 2). The multivariate analysis conducted in Table 3 also provided a similar result where the mother's body weight was the only variable which statistically significant $(\mathrm{p}=0.002)$ compare with others.

In this study, an analysis of the correlation between Mid-Parental Height (MPH) and body height of the child was carried out using the Pearson correlation test. It was obtained that the correlation coefficient is 0.41 , and the p-value also $<0.01$. The correlation coefficient is included in the moderate correlation (Table 4). 
Table 1 Baseline characteristic of respondents

\begin{tabular}{|c|c|c|}
\hline Characteristics & Frequency $(n=123)$ & Mean \pm SD \\
\hline Age of Children (months) & & $28.9 \pm 12.5$ \\
\hline \multicolumn{3}{|l|}{ Gender (n,\%) } \\
\hline Male & $57(46.3)$ & \\
\hline Female & $66(53.7)$ & \\
\hline Children Body Height (n,\%)(cm) & & $85.4 \pm 9.8$ \\
\hline Normal & $83(67.5)$ & \\
\hline Stunting & $40(32.5)$ & \\
\hline Children Body Weight (n,\%)(kg) & & $10.9 \pm 2.1$ \\
\hline Normal & $120(97.6)$ & \\
\hline Underweight & $3(2.4)$ & \\
\hline Mother's Body Height (n,\%) & & $156 \pm 6.9$ \\
\hline$<155 \mathrm{~cm}$ & $43(35.0)$ & \\
\hline$>155 \mathrm{~cm}$ & $80(65.0)$ & \\
\hline Father's Body Height (n,\%)(cm) & & $161 \pm 9.5$ \\
\hline$<165 \mathrm{~cm}$ & $46(37.4)$ & \\
\hline$>165 \mathrm{~cm}$ & 77 (62.6) & \\
\hline Mid-Parental Height $(\mathrm{MPH})(\mathrm{cm})$ & & $158 \pm 9.8$ \\
\hline
\end{tabular}

Table 2 The association between body height of parents with stunting

\begin{tabular}{lcccccc}
\hline & & \multicolumn{2}{c}{ Child's Body Height } & & & \\
\cline { 3 - 5 } Variables & & $\begin{array}{c}\text { Stunting } \\
\text { (n,\%) }\end{array}$ & $\begin{array}{c}\text { Not Stunting } \\
\text { (n,\%) }\end{array}$ & p & PR & Cl 95\% \\
\hline Father's Body Height & $<165 \mathrm{~cm}$ & $13(28.3)$ & $33(71.7)$ & 0.436 & 0.806 & $0.46-1.39$ \\
& $\geq 165 \mathrm{~cm}$ & $27(35.1)$ & $50(64.9)$ & & & \\
Mother's Body Height & $<155 \mathrm{~cm}$ & $22(51.2)$ & $21(48.8)$ & $<0.01$ & 2.27 & $1.37-3.75$ \\
& $\geq 155 \mathrm{~cm}$ & $18(22.5)$ & $62(77.5)$ & & & \\
\hline
\end{tabular}

Table 3 Multivariate Analysis

\begin{tabular}{lcc}
\hline Variables & P & Exp (B) \\
\hline Mother's Body Height & 0.002 & 3.743 \\
Father's Body Height & 0.305 & 0.641 \\
BW/BH & 0.914 & 0.938 \\
Gender & 0.035 & 2.398 \\
\hline
\end{tabular}

Table 4 Correlation of MPH on Body Height

\begin{tabular}{lcc}
\hline Variables & $\boldsymbol{P}$ & $\boldsymbol{r}$ \\
\hline Mid-Parental Height (MPH) and Children Body Height & $<0.01$ & 0.41 \\
\hline
\end{tabular}

\section{DISCUSSION}

In this study, it was found that $32.5 \%$ of children were stunting. Based on the chi-square test, it was found that there was no significant association between the father's body height on stunting. Meanwhile, there was a significant association between a mother's body height and stunting.
In this study, MPH correlation analysis was also carried out on the children's body height. A study conducted by Lestari found that parental height is a factor that affects the birth length of a baby, then it was also mentioned in the study that one of the stunting risk factors was the body height of parents 
with 11.3 times higher. ${ }^{8}$ The research conducted by Oktarina and Sudiarti for children aged 2-5 years in Sumatra found that stunting risk factors that had statistically significant value included mother's body height, level of fat intake, number of family members, and sources of drinking water. ${ }^{9}$ In this study, it was found that there was no significant association between father's body height and stunting. This result is following the research that conducted by Amin and Julia stated there is no significant association between father's body height on stunting. ${ }^{10}$ This result is likely due to mistakes in filling out the questionnaires related to recall bias. The second possibility is, in this study, the measured variable was done once, and no further monitoring was carried out, meanwhile, to assess the association between father's body height to stunting required continuous monitoring.

Growth is an ongoing process of human physical changes (aspects of shape and size) until it reaches a certain level of functional and biological maturity, growth occurs due to the process of hyperplasia and cell hypertrophy. ${ }^{11}$ Factors that influence growth include adequate nutrition, a growth-supporting environment, normal chromosomes, health, and good hormones regulation. ${ }^{12}$ Genes that carried out the regulation of body height affect the hormones that play a role in the growth process; they are thyroid hormones, insulin, sex steroids (estrogen and testosterone), glucocorticoids, vitamin $\mathrm{D}$ and parathyroid hormones. Thyroid hormones have a direct effect on the differentiation and maturation of cartilage cells (epiphyses) by increasing the production of growth hormone and IGF-1. In contrast, insulin hormone works by affecting indirect growth through energy distribution. Glucocorticoid hormones work by suppressing bone synthesis and cartilage and inhibits bone mineralization so that no excessive growth occurs, vitamin $\mathrm{D}$ and parathyroid hormones play a role in the occurrence of osteogenesis. ${ }^{13,14}$ The child's height is very related to body proportions. The upper-to-lower (U/L) body segment ratio indicates whether a child has an appropriate or proportionate proportion (involving both the body and lower extremity) or disproportionate (including only one part). The lower part of the body is calculated based on the distance between the edges of the symphysis pubis to the floor where the patient is standing (not wearing shoes). The upper part is calculated by reducing the body height with the height of the lower part of the body..$^{15}$ The U/L ratio obtained, then compared according to age and sex. The $\mathrm{U} / \mathrm{L}$ ratio typically decreases progressively from birth and reaches its peak in early puberty. At the onset of puberty, the U/L ratio increases slightly until the epiphyseal closes. ${ }^{15}$ One disease that is characterized by the presence of $\mathrm{U} / \mathrm{L}$, which is lower than the age is skeletal dysplasia. Meanwhile, a condition characterized by $\mathrm{U} / \mathrm{L}$ that is higher than the age is achondroplasia, afterwards, an increase in U/L is also found in children who experience precocious puberty.

In this study, besides analyzing the father's body height on stunting, an analysis of the association between mother's body height and stunting with the results of the analysis showed that there was a significant association between the mother's body height with PR 2.27 and a confidence interval of 1.37-3.75. Several studies have shown a significant association between mother's body height and stunting, a study conducted by Zotarelli in Egypt, which states that mothers who have a height below $150 \mathrm{~cm}$ are more at risk of having a stunting child than mothers who have a height above $150 \mathrm{~cm} .{ }^{16}$ Study conducted by Amin and Julia showed there was a significant association between mother's body height and the incidence of stunting with adjusted OR 2.04 and confidence interval of 1.14-3.65. ${ }^{10}$ The research conducted by Ratu and Punuh also showed a significant association between the mother's body height and stunting. ${ }^{17}$ Besides, a study conducted by Nasikhah and Margawati by multivariate analysis with logistic regression showed that mother's body height was one of the risk factors for stunting, then other factors that affect significantly are father's body height, low education, and low income. ${ }^{18}$

In this study, a correlation analysis of mid parental height with the child's body height was conducted, and it was found that mid parental height had a correlation coefficient with a child's height of 0.4 , which conclude that into moderate correlation category. Some studies such as those conducted by WHO found that the mid parental height correlation coefficient with 2 years old children in the United States was 0.59, then in Brazil 0.42 , Ghana 0.44 , India 0.49 , Norway 0.51 , and Oman 0.39. ${ }^{19}$ Parents' body height and growth patterns are essential to know the growth pattern of children. Genetic factors do not appear at birth but will manifest after the age of 2-3 years. Correlation between body height of children and mid parental height (MPH) is 0.5 at age two years old and becomes 0.7 at adolescence as mentioned by the previous study. ${ }^{20}$

This study is limited in terms of cross-sectional research design where causality cannot be determined in this study and data is not followed up for a certain period. Data retrieval that used questionnaires has a weakness in terms of recall bias, where respondents can fill out questionnaires with things that are not related to reality due to forgetting matters. The study sample was only taken from one region, so it did not represent a real situation in a 
more significant population. Future studies with a multicenter prospective cohort design might be carried out to see the effect of protein intake from animal sources on the incidence of stunting.

\section{CONCLUSION}

In this study, it was found that there were $32.5 \%$ of children experiencing stunting. There was no statistically significant association between the father's body height and the incidence of stunting. Meanwhile, the association between maternal height and stunting incidence was found to be statistically significant. In this study, an analysis of the correlation between mid-parental height and the child's body height was also carried out, and the results were in moderate correlation. This is because the genetic factors begin to influence the child's body height when the child is two years old.

\section{CONFLICT OF INTEREST}

There is no competing interest regarding the manuscript.

\section{ETHICS CONSIDERATION}

Ethics approval has been obtained before the study being conducted from the Ethics Committee, Faculty of Medicine, Universitas Udayana, Sanglah General Hospital, Bali, Indonesia.

\section{FUNDING}

None.

\section{AUTHOR CONTRIBUTION}

All of the authors are equally contributed to the study from the conceptual framework until interpreting the results of the study through publication.

\section{REFERENCES}

1. Pryer JA, Rogers S, Rahman A. The epidemiology of good nutritional status among children from a population with a high prevalence of malnutrition. Public Health Nutr. 2004;7(2):311-317.

2. Ge KY, Chang SY. Definition and measurement of child malnutrition. Biomed Environ Sci. 2001;14(4):283-291.

3. Milman A, Frongillo EA, de Onis M, Hwang JY. Differential improvement among countries in child stunting is associated with long-term development and specific interventions. J Nutr. 2005;135(6):1415-1422.
4. Kusharisupeni. Growth Faltering pada Bayi di Kabupaten Indramayu Jawa Barat. Makara Kesehatan. 2002;6(1):1-5.

5. Shrimpton R, Victora CG, de Onis M, Lima RC, Blössner M, Clugston G. Worldwide timing of growth faltering: implications for nutritional interventions. Pediatrics. 2001;107(5):E75.

6. Beal T, Tumilowicz A, Sutrisna A, Izwardy D, Neufeld LM. A review of child stunting determinants in Indonesia. Matern Child Nutr. 2018;14(4):e12617.

7. Kementrian Kesehatan Republik Indonesia. Buku Saku Pemantauan Status Gizi Tahun 2017. Jakarta: Direktorat Gizi Masyarakat Direktorat Jenderal Kesehatan Masyarakat Kementerian Kesehatan, 2018.

8. Lestari W, Margawati A, Rahfiludin Z. Faktor Risiko Stunting Pada Anak Umur 6-24 bulan di Kecamatan Penanggalan kota Subulussalam Provinsi Aceh. Jurnal Gizi Indonesia. 2014;3(1):126-34.

9. Oktarina Z., Sudiarti T. Faktor Risiko Stunting pada Balita 24-59 Bulan di Sumatera. J Gizi Pangan. 2014;8(3):175-80.

10. Amin NA, Julia M. Faktor Sosiodemografi dan Tinggi Badan Orang Tua Serta Hubungannya dengan Kejadian Stunting pada balita usia 6-23 bulan. IJND. 2014;2(3):170-77.

11. Arce M. Early childhood growth and development. Rev Peru Med Exp Salud Publica. 2015;32(3):574-578.

12. de Onis M, Garza C, Onyango AW, Rolland-Cachera MF; le Comité de nutrition de la Société française de pédiatrie. WHO growth standards for infants and young children. Arch Pediatr. 2009;16(1):47-53.

13. Bassett JH, Williams GR. Role of Thyroid Hormones in Skeletal Development and Bone Maintenance. Endocr Rev. 2016;37(2):135-187.

14. Reible B, Schmidmaier G, Moghaddam A, Westhauser F. Insulin-Like Growth Factor-1 as a Possible Alternative to Bone Morphogenetic Protein-7 to Induce Osteogenic Differentiation of Human Mesenchymal Stem Cells in Vitro. Int J Mol Sci. 2018;19(6):1674.

15. Louer AL, Simon DN, Switkowski KM, Rifas-Shiman SL, Gillman MW, Oken E. Assessment of Child Anthropometry in a Large Epidemiologic Study. J Vis Exp. 2017;(120):54895.

16. Zottarelli LK, Sunil TS, Rajaram S. Influence of parental and socioeconomic factors on stunting in children under 5 years in Egypt. East Mediterr Health J. 2007;13(6):1330-1342.

17. Ratu NC, Punuh MI, Malonda NSH. Hubungan Tinggi Badan Orangtua Dengan Kejadian Stunting Pada Anak Usia 24-59 bulan di Kecamatan Ratahan Kabupaten Minahasa Tenggara. Jurnal Kesehatan Masyarakat. 2018;7(4):1-8

18. Nasikhah R, Margawati A. Faktor Risiko Kejadian Stunting Pada Balita Usia 24 - 36 Bulan Di Kecamatan Semarang Timur. Journal of Nutrition College. 2012;1(1):176-84.

19. Garza C, Borghi E, Onyango AW, de Onis M; WHO Multicentre Growth Reference Study Group. Parental height and child growth from birth to 2 years in the WHO Multicentre Growth Reference Study. Matern Child Nutr. 2013;9 Suppl 2:58-68.

20. Mediana S, Pratiwi R. Hubungan Antara Jumlah Konsumsi Susu Formula Standar Terhadap Kejadian Stunting Pada Anak Usia 2-5 tahun. Jurnal Kedokteran Diponegoro. 2016;5(4):1743-51.

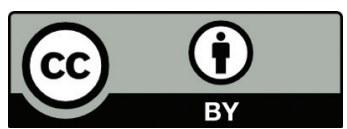

This work is licensed under a Creative Commons Attribution 